\title{
BIBLIOGRAFIA ESPECIALIZADA SOBRE A TELENOVELA BRASILEIRA
}

\author{
BIOGRAFIAS
}

SFAT, Dina; CABALLERO, Mara. Dina Sfat: palmas pra que te quero. Rio de Janeiro: Nórdica, 1988. 255p.

Biografia da atriz de cinema, teatro e televisão Dina Sfat. Contém relação de filmes, peças teatrais, telenovelas e seriados dos quais participou.

Palavras-chave: Dina Sfat/Atriz/Teatro/Seriados

N. Cham.: $1791.45 /$ Sfat

Loc. Doc.: BT/ECA/USP2

\section{ENSAIOS E PESQUISAS}

LASAGNI, Cristina; RICHERI, Guiseppe. L'altro mondo quotidiano: telenovelas, TV brasiliana e d'intorni. Torino: ERI, 1986. 127p.

A telenovela brasileira é analisada a partir da história da televisão no Brasil, desde suas origens no ano de 1950. Aponta o desenvolvimento dessa indústria em sua relação com a situação econômica e política, dando ênfase à Doutrina de Segurança Nacional. Depois analisa o surgimento da Rede Globo e sua relação com as outras redes de TV. A telenovela também é vista desde sua origem e a partir de telenovelas que marcaram época, como $\mathbf{O}$ direito de nascer, Beto Rockfeller e, por fim, Roque Santeiro, até hoje o maior sucesso. O livro ainda inclui um capítulo sobre a história da telenovela venezuelana e outro sobre as séries brasileiras de maior sucesso, substituta das séries norte-americanas, como Dallas. Apresenta, ainda, dois apêndices: um

\section{A AUTORA}

Anamaria Fadul

Professora Titular do Departamento de Comunicações e Artes da ECA-USP e Coordenadora do Núcleo de Pesquisa de Telenovela deste Departamento.

1. Número de chamada.

2. Localização do documento na Biblioteca da ECA-USP. Av. Lúcio Martins Rodrigues, 443 - Fone: (011) 818-4047. São Paulo - SP 05508-900. 
sobre a televisão brasileira e o grupo Globo e outro sobre as telenovelas exibidas nas cinco televisões e seus respectivos horários.

Palavras-chave: História da televisão/Rede Globo/Origens/Evolução/Venezuela/Séries brasileiras/Telenovela

N. Cham.: 701.450981/L337a

Loc. Doc.: BT/ECA/USP

\section{CAPÍTULOS DE LIVROS}

MORAN COSTAS, José Manuel. A mulher na telenovela. In: SANTANA, Carmita; DIDONÉ, Iraci Maria (orgs). Meu nome é mulher: temas para debate. São Paulo: Loyola, 1990. p.41-44.

A mulher aparece na telenovela como consumidora principal de produtos, de emoções e como ingrediente importante das histórias, mostrando modelos contraditórios de comportamento.

Palavras-chave: Mulher/Merchandising/Valores

\section{REVISTAS ESPECIALIZADAS}

BALOGH, Ana Maria. Televisão: serialidade, parasserialidade e repetição. Face: Revista de Semiótica e Comunicação, São Paulo, v.3, n.1, jan./jun. de 1990, p.109-117.

Análise da produção televisual principalmente sob a ótica da serialidade e dos formatos. Análise do mosaico de novelas da Globo, no horário nobre, determinação de seus elementos constantes com relação ao tema, gênero, elementos estéticos do vídeo etc.

Palavras-chave: Serialidade/Rede Globo/Horário nobre/Gêneros

Loc. Doc.: BT/ECA/USP

BILTEREYST, Daniel. As telenovelas e o público flamengo: análise multidisciplinar da recepção das séries brasileiras entre o público belga de língua holandesa. Intercom: Revista Brasileira de Comunicação, São Paulo, v.13, n.62/63, 1990, p.81-85.

Analisa a recepção das telenovelas brasileiras entre o público belga de língua holandesa. Discute o caso da Belgische Rádio en Televise (BRT), Rede Belga de Rádio e Televisão, constatando que a estratégia geral de programação da televisão influencia a recepção das telenovelas pelo público. Destaca, nas discussões, duas telenovelas que alcançaram bons índices de audiência na Bélgica: Sinhá Moça e Escrava Isaura. 
Palavras-chave: Recepção/Público de língua holandesa/Programação de televisão/Bélgica N.Cham.: 301.16

Loc. Doc.: BT/ECA/USP

FADUL, Anamaria. Brasil: el exito de la telenovela. Chasqui: Revista Latinoamericana de Comunicación, Quito, n.25, ene./mar. de 1988, p.16-21.

Reavaliação do papel da telenovela brasileira, partindo de sua análise enquanto gênero televisivo de maior sucesso no país, constituidora de um processo de abrasileiramento que teve nas relações com o público o seu principal ponto de partida. Esse reexame é feito através da questão da representação das várias identidades nacionais nas telenovelas ao longo de sua história. Por ser impossível falar dessas identidades nacionais a partir de mais de 500 telenovelas, a autora seleciona algumas mais representativas dos perfis da mulher, do negro, do imigrante, do índio e de atividades tais como o futebol, o jogo-do-bicho e o carnaval.

Palavras-chave: Cultura brasileira/Gênero/Abrasileiramento/Identidades nacionais

N. Cham.: 301.16

Loc. Doc.: BT/ECA/USP

SOUSA, Mauro Wílton de. Jovens e a telenovela de cada dia. Revista de Educação da Associação de Escolas Católicas-AEC, Brasilia, v.17, n.69, jul./set. de 1988, p.26-37.

O texto procura mostrar como jovens de classe média urbana de grandes centros como São Paulo traduzem a telenovela no espaço cotidiano de suas vidas. Apesar de despertar atitudes aparentemente antagônicas, a telenovela vem exercendo uma mediação crescente junto aos jovens, pois ela diverte, informa, conta histórias e estabelece novas relações entre ficção e realidade.

Palavras-chave: Jovens/Classe média urbana/Mediação/São Paulo

Loc. Doc.: BT/ECA/USP

N. Cham.:

\section{DISSERTAÇÕES MESTRADO}

KROPF, Maria Helena. Contribuições de voz e fala para o ator de telenovela. São Paulo: Escola de Comunicações e Artes. Universidade de São Paulo, 1990, 149p.(mimeo.)

Orientador(a): SANTOS, Yolanda Lhulier dos.

Analisa os elementos da voz e da fala e suas contribuições para o enriquecimento do ator de telenovela. Discute a necessidade da compreensão de que a voz e a fala são ele- 
mentos que valorizam o trabalho de interpretação. Busca conscientizar o ator do processo que se realiza diante das câmeras. Apresenta um breve histórico da voz e da fala no teatro, rádio e televisão.

Palavras-chave: Voz e fala do ator/Teatro/Rádio/Televisão

N. Cham.: t791.45/Kropf

Loc. Doc.: BT/ECA/USP

PENTEADO, Heloísa Dupas. A televisão e os adolescentes: a sedução dos inocentes. São Paulo: Faculdade de Filosofia, Letras e Ciências Humanas. Universidade de São Paulo, 1979, 176p.(mimeo.)

Orientador(a): GOUVEIA, Aparecida Joly.

Análise da relação consumo de TV e tipo de escola frequientada pelo consumidor adolescente. A pesquisa foi feita com adolescentes de oitavas séries de escolas públicas estaduais. O programa escolhido para verificar como os adolescentes dessas escolas consumiam um programa de TV foi a telenovela Estúpido Cupido. Foram organizados grupos de discussão para avaliar se havia um consumo crítico ou passivo por parte dos adolescentes. $O$ resultado da pesquisa é que a TV junto aos adolescentes é eficiente veículo da sociedade de consumo a serviço da qual funciona.

Palavras-chave: Adolescentes/Escolas Públicas/Consumo/Manipulação

N. Cham.: t791.450981/419t

Loc. Doc.: BT/ECA/USP 